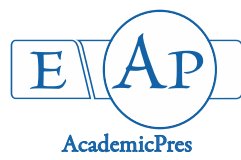

\title{
Incidence of Common and Rare Cancers in Ilorin, Nigeria
}

\author{
Abass T. ANIFOWOSHE*, Olubukola A. OWOLODUN, \\ Bashirudeen O. OYINLOLA, Kazeem ABDULGANIYU, \\ Robiat D. YUSUF, Oyinkansola A. OREDEIN, Oluyinka A. IYIOLA \\ University of Ilorin, Faculty of Life Sciences, Department of Zoology, Cell Biology and Genetics Unit, Ilorin, \\ Nigeria; anifowoshe.at@unilorin.edu.ng; abassgenetics@gmail.com (*corresponding author)
}

\begin{abstract}
Cancer is a public health problem worldwide, affecting all categories of persons. It is the second common cause of death in developed countries and among the three leading causes of death in developing countries. Due to its genetics and medical importance, study on its incidence is germane. In the present study, 74 different cancers of 2,246 $(\mathrm{n}=891 \mathrm{male}$ and $\mathrm{n}=1355$ female) cancer patients within the age of 1-105 in Nigeria were retrospectively reviewed using the data from University of Ilorin Teaching Hospital (UITH). The overall profile of the categories showed the leading position of breast cancer, followed by cancer of the digestive system (32.29\% and $19.67 \%$, respectively), while Kaposi sarcoma, endocrine system and brain cancers were among the rare or least recorded $(<1.0 \%$ incidence rate). Furthermore, the trend showed a high prevalence during 2011 and 2015 (>13\% and $>11 \%)$ than any other year within the study, while the lowest incidence was recorded in $2016(<6 \%)$. Predisposing factors like tumorigenesis, immune system, biological stressors as well as gene-environment interaction and low life expectancy could influence the risk of different groups of cancer. Therefore, future investigations should be targeted on risk factors related to those considered rare so as to provide useful information about possible signs and symptoms for diagnosis before it escalate.
\end{abstract}

Keywords: common cancer; Ilorin; incidence; Nigeria; rare cancer

\section{Introduction}

Cancer is said to be the leading cause of death in developed countries and the $2^{\text {nd }}$ leading cause in developing countries (Torre et al., 2015). Presently, $57 \%$ of the global cancer burden and $65 \%$ of cancer deaths are from less developed regions in Africa, Asia (excluding Japan), Latin America and the Caribbean. It is a genetic disease caused mainly by environmental factors. It was described by Ikawo (2013) as a group of diseases characterized by unregulated division and spread of cells.

They occur mostly as solid tumours which appear in various tissues in different parts of the body. However, some are known to appear in body fluid (as seen in leukaemia). Malcom (2001) suggested that over $90 \%$ of cancers occur in epithelial cell, being the main covering of the skin, the respiratory and alimentary tracts, where the ingested carcinogens pass through. He based his assumption on the possibility of having only certain polyunsaturated fatty acids generating damaging free radicals, wherein, the intake level of antioxidant vitamins that can scavenge these harmful radicals is a confounding factor. There are multiple factors that may cause cancer and it is difficult to pin point an exact cause. One of the possible causes of cancer is DNA damage, which may be inherited from parents or may be a spontaneous problem that occurs during the individual's life time. It is also referred to as mutation(s). DNA damage may also be triggered by exposure to certain environmental toxins such as those present in cigarette smoke. Although there are about two hundred (200) known types of cancers, they are classified based on their location in the body. They include lung, colon, breast, prostate, cervical cancer, etc.

According to Ferlay et al. (2008), about 100,000 new cases of cancer occur every year in Nigeria, with high case fatality ratio. Furthermore, Nigeria was said to have contributed $15 \%$ to the estimated 681,000 new cases of cancer in Africa for the year 2008. The significant increase in incidence of cancer in Nigeria is implicated to be due to increasing life expectancy (with most cancers being more common in an ageing population), population growth, reduced risk of death from infectious diseases, increasing prevalence of smoking, physical inactivity, obesity, as well as changing dietary and lifestyle patterns (Sylla and Wild, 
454

2012). The problem facing diagnosis of cancer patients in developing countries like Nigeria include lack of facilities (WHEDA, 2004; Lambo, 2007; Durosinmi, 2008), poor awareness (especially for the less common cancers), socioeconomic background among others.

In recent times, information on cancer incidence, prevalence and mortality in Nigeria has been based on estimates from case series, medical records, mortality records, hospital-based cancer registries and the Ibadan population-based cancer registry (IBCR) (Bah et al., 2011). IBCR, located at the University College Hospital Ibadan, set up in 1962, is the first cancer registry in Nigeria. In view of this, the Federal Ministry of Health (FMOH) and the Institute of Human Virology Nigeria (IHVN) have initiated in 2009 a program of National System of Cancer Registries, hence, the aim of this study.

According to World Health Organization (2008), common risk factors for cancer include: tobacco use, alcohol use, overweight and obesity. The common symptoms of cancer which includes the symptoms at the primary site of cancer are either lump or tumour, pain, bleeding, ulcers or sores over the skin, pressure over the surrounding organs, hoarseness or cough that does not go away, obvious changes that appears like a wart or a mole, changes in bladder or bowel habits, difficulty in swallowing (Ananya, 2012). Other symptoms might be generalized for the body as a whole. Most of these general symptoms are common for all types of cancer. These include weight loss, poor appetite, fatigue and wasting (known as cancer cachexia), excessive sweating especially at nights (night sweats), hormonal changes, anaemia and bleeding tendencies due to deficiency of platelets (thrombocytopenia) (Ananya, 2012).

As with most illnesses, cancer is multifactorial, meaning there is no single cause for any one type of cancer. Thus, in the present investigation, are presented the estimates of cancer incidence in Ilorin, Kwara state, Nigeria, based on the data collected from University of Ilorin Teaching Hospital (UITH) cancer registry between the period of 2007 and 2016.

\section{Materials and Methods}

This is a retrospective hospital-based study conducted at the registry of University of Ilorin Teaching Hospital (UITH) with the Latitude and Longitude of $8.5372^{\circ} \mathrm{N}$ and $4.6474^{\circ}$ E respectively from 2007-2016 in Ilorin, Kwara State. A total of 2,246 cancer patients between the ages of 1 105 were enrolled. They were made up of 891 males and 1,355 females. The UITH registry is one assessed as "active" by the National Secretariat of the cancer registries during the period of study. The registry uses International Classification of Disease for Oncology, $3^{\text {rd }}$ Edition (ICDO3) (Fritz et al., 2000) for classification and coding and CanReg4 software for storing, checking and processing data. All quality control checks and duplication checks were performed by the cancer registry and repeated by the Cancer Registry Coordinator at the Institute of Human Virology, Nigeria. They were checked for duplication of cases in the registry database. The specific information collected from the record of cancer patients included age, sex, cancer site and the town of residence.
The cancers were categorized into 16 groups, while part of the investigated data, based on the broad systems and specific "sites" employed by the SEER Site Recode scheme, which is predominantly anatomically based, but also includes exclusive categories for several histologically, were defined as neoplasms (Ries et al., 2008). The examined distinct anatomic locations that are subsumed within broader site categories are those which would not typically be identified separately in standard cancer surveillance reports.

The resultant cancer groups are oral cancer, gastrointestine, liver, internal organ, glands, respiratory system, bone, skin, breast, cervical, prostate, urinary system, eye, brain/nervous system and leukaemia/lymphoma.

\section{Statistical analysis}

All statistical analyses were carried out using IBM 20.0 statistical software. The reported cases of cancer were collated and summarised using frequency and percentage. Different cancer incidence in the state was computed using the standard method of Olusegun (2014).

\section{Results}

The Fig. 1, below, shows the prevalence of cancer between 2007 and 2016 in Ilorin, Kwara state Nigeria as recorded at the cancer registry of the UITH. The trend showed a high prevalence in 2011 and 2015 (>13\% and $>11 \%)$ than any other year within the study. In contrast, the lowest incidence was recorded in 2016 (<6\%). The overall profile of the categories shows the leading position of breast cancer, followed by cancer of the digestive system $(32.29 \%$ and $19.67 \%$ respectively), while Kaposi sarcoma, lymphoma, endocrine system, soft tissue and brain cancers were the least (with $<1.0 \%$ incidence rate). Other cancer groups recorded were between $1.0 \%$ and $4.0 \%$ each. Furthermore, the incidence rate for cancer affecting both the male and female genital system was between $10 \%$ and 15\% (Table 1, Table 2 and Fig. 1).

The cancer incidence by various cancer sites from UITH registry between 2007-2016 is shown in Fig. 2.

Some selected rare cancer forms, from both male and female group, are shown in Table 3, with cervix cancer having the highest incidence rate $(<10 \%)$, while the others are below $3 \%$ of the overall incidence recorded.

The most common cancers among male (prostate, liver and colorectal) and female (breast, cervical and leukaemia carcinomas) are summarised in Table 4. Figs. 3 and 4 show the trend of common cancers among male and female, respectively, while Fig. 5 shows age characteristic of some selected cancer groups in Nigeria from the Ilorin registry.

\section{Discussion}

Analysis of cancer pattern among different states in Nigeria undertaken by Olusegun (2014) using retrospective cancer data from different national registries from 19871996 showed that cancer incidence varied significantly ( $P$ $<0.05$ ) among states. In respect to this, cancer incidence in Ilorin, Kwara State, Nigeria was investigated. 
Table 1. Relative frequency of cancer cases in University of Ilorin Teaching Hospital between 2007-2016

\begin{tabular}{|c|c|c|c|c|c|c|c|c|c|c|c|}
\hline Cancer type & 2007 & 2008 & 2009 & 2010 & 2011 & 2012 & 2013 & 2014 & 2015 & 2016 & Total \\
\hline Adenocarcinoma & 1 & 0 & 0 & 1 & 0 & 0 & 0 & 0 & 0 & 1 & 3 \\
\hline Anorectal & 0 & 0 & 0 & 0 & 0 & 1 & 0 & 0 & 0 & 0 & 1 \\
\hline Anus & 1 & 6 & 3 & 2 & 1 & 0 & 2 & 7 & 3 & 0 & 25 \\
\hline Arm & 0 & 0 & 0 & 0 & 0 & 1 & 0 & 0 & 0 & 0 & 1 \\
\hline Ascistic fluid & 1 & 2 & 1 & 0 & 1 & 0 & 1 & 0 & 0 & 0 & 6 \\
\hline Axillary & 3 & 3 & 6 & 9 & 2 & 2 & 0 & 0 & 0 & 0 & 25 \\
\hline Bladder & 6 & 4 & 5 & 6 & 3 & 7 & 5 & 2 & 10 & 2 & 50 \\
\hline Blood-Leukemia & 4 & 5 & 0 & 0 & 0 & 3 & 8 & 11 & 8 & 0 & 39 \\
\hline Bowel & 0 & 0 & 0 & 0 & 1 & 0 & 0 & 1 & 1 & 0 & 3 \\
\hline Brain & 1 & 1 & 1 & 0 & 0 & 0 & 1 & 0 & 0 & 0 & 4 \\
\hline Breast & 72 & 62 & 64 & 73 & 107 & 81 & 56 & 61 & 89 & 39 & 704 \\
\hline Burkitts & 2 & 0 & 0 & 0 & 0 & 0 & 0 & 0 & 0 & 0 & 2 \\
\hline Caecum & 2 & 2 & 0 & 0 & 0 & 0 & 2 & 0 & 0 & 0 & 6 \\
\hline Cervical & 0 & 1 & 2 & 0 & 28 & 0 & 0 & 0 & 0 & 0 & 31 \\
\hline Cervix & 17 & 19 & 0 & 0 & 28 & 0 & 22 & 18 & 16 & 5 & 125 \\
\hline Cheek & 0 & 0 & 0 & 0 & 0 & 1 & 0 & 0 & 0 & 0 & 1 \\
\hline Clavicular & 0 & 0 & 1 & 2 & 0 & 0 & 0 & 0 & 1 & 0 & 4 \\
\hline Colon & 9 & 5 & 4 & 4 & 6 & 8 & 0 & 0 & 9 & 5 & 50 \\
\hline Ear & 0 & 0 & 0 & 0 & 0 & 1 & 0 & 0 & 1 & 0 & 2 \\
\hline Endomentrum & 6 & 3 & 2 & 3 & 0 & 0 & 4 & 0 & 1 & 0 & 19 \\
\hline Eye & 5 & 7 & 8 & 9 & 7 & 9 & 3 & 6 & 5 & 1 & 60 \\
\hline Frontal mass & 1 & 0 & 0 & 0 & 0 & 0 & 0 & 0 & 0 & 3 & 4 \\
\hline Foot & 0 & 0 & 0 & 0 & 2 & 0 & 0 & 0 & 0 & 0 & 2 \\
\hline Genital tract & 0 & 0 & 0 & 0 & 0 & 0 & 1 & 0 & 0 & 0 & 1 \\
\hline Hand & 0 & 1 & 0 & 2 & 0 & 0 & 0 & 1 & 0 & 0 & 4 \\
\hline Hard palate & 0 & 0 & 0 & 0 & 1 & 0 & 0 & 0 & 0 & 0 & 1 \\
\hline Hodgkin disease & 1 & 3 & 0 & 2 & 0 & 0 & 0 & 0 & 0 & 0 & 6 \\
\hline Intestine & 0 & 0 & 0 & 1 & 1 & 0 & 0 & 0 & 1 & 0 & 3 \\
\hline Kaposi sarcoma & 0 & 0 & 1 & 0 & 0 & 0 & 0 & 0 & 0 & 0 & 1 \\
\hline Kidney & 0 & 3 & 1 & 3 & 5 & 2 & 9 & 0 & 0 & 1 & 24 \\
\hline Knee & 0 & 0 & 0 & 0 & 1 & 0 & 0 & 0 & 0 & 0 & 1 \\
\hline Labia Majora & 0 & 0 & 0 & 0 & 1 & 0 & 0 & 0 & 0 & 0 & 1 \\
\hline Larynx & 0 & 5 & 3 & 3 & 0 & 2 & 2 & 0 & 1 & 1 & 17 \\
\hline Leg & 0 & 0 & 12 & 4 & 3 & 4 & 9 & 0 & 2 & 0 & 34 \\
\hline Liver & 13 & 15 & 1 & 5 & 15 & 17 & 22 & 25 & 13 & 19 & 145 \\
\hline Lung & 1 & 1 & 0 & 4 & 1 & 3 & 2 & 9 & 3 & 4 & 28 \\
\hline Lymphnode & 1 & 0 & 1 & 1 & 9 & 7 & 5 & 2 & 3 & 3 & 32 \\
\hline Mandibular & 6 & 3 & 3 & 1 & 0 & 0 & 3 & 5 & 6 & 1 & 28 \\
\hline Maxillary & 1 & 0 & 0 & 0 & 0 & 0 & 0 & 0 & 0 & 0 & 1 \\
\hline Mesentric & 0 & 0 & 0 & 1 & 0 & 0 & 0 & 1 & 0 & 0 & 2 \\
\hline Mouth & 1 & 0 & 1 & 0 & 1 & 1 & 1 & 1 & 0 & 0 & 6 \\
\hline Multiple myeloma & 4 & 3 & 0 & 1 & 0 & 0 & 0 & 0 & 0 & 0 & 8 \\
\hline Neck & 5 & 0 & 2 & 0 & 2 & 0 & 2 & 4 & 3 & 1 & 19 \\
\hline Nephroblastoma & 0 & 0 & 1 & 0 & 0 & 6 & 0 & 0 & 0 & 0 & 7 \\
\hline Non-Hodgkin & 0 & 0 & 0 & 3 & 0 & 0 & 0 & 0 & 0 & 0 & 3 \\
\hline Nose & 3 & 3 & 3 & 1 & 1 & 0 & 6 & 2 & 2 & 3 & 24 \\
\hline Oesophagus & 0 & 1 & 1 & 2 & 0 & 2 & 1 & 3 & 0 & 3 & 13 \\
\hline Omentum & 0 & 2 & 1 & 0 & 3 & 4 & 0 & 0 & 0 & 0 & 10 \\
\hline Oropharynx & 0 & 1 & 0 & 0 & 0 & 0 & 1 & 0 & 0 & 0 & 2 \\
\hline Ovary & 2 & 1 & 2 & 6 & 7 & 4 & 2 & 4 & 5 & 0 & 33 \\
\hline Pancreas & 1 & 0 & 0 & 0 & 0 & 1 & 3 & 1 & 2 & 0 & 8 \\
\hline Parotid gland & 1 & 0 & 0 & 0 & 0 & 0 & 0 & 0 & 1 & 0 & 2 \\
\hline Penis & 0 & 0 & 0 & 0 & 1 & 1 & 0 & 0 & 0 & 0 & 2 \\
\hline Pharynx & 1 & 0 & 0 & 0 & 0 & 0 & 0 & 0 & 0 & 0 & 1 \\
\hline Pleural & 0 & 0 & 0 & 0 & 2 & 1 & 0 & 0 & 1 & 0 & 4 \\
\hline Prostate & 33 & 32 & 32 & 29 & 34 & 35 & 37 & 22 & 56 & 24 & 334 \\
\hline Rectum & 9 & 8 & 8 & 5 & 8 & 18 & 2 & 6 & 7 & 5 & 76 \\
\hline Retroperitoneal & 0 & 0 & 1 & 0 & 0 & 0 & 0 & 0 & 0 & 0 & 1 \\
\hline Salivary gland & 0 & 0 & 1 & 0 & 0 & 0 & 0 & 0 & 0 & 0 & 1 \\
\hline Scapular & 2 & 0 & 0 & 0 & 1 & 1 & 1 & 1 & 1 & 0 & 7 \\
\hline Scrotal & 0 & 0 & 0 & 0 & 0 & 1 & 0 & 0 & 0 & 0 & 1 \\
\hline Skin & 1 & 4 & 2 & 2 & 3 & 5 & 2 & 0 & 0 & 5 & 24 \\
\hline Soft palate & 0 & 0 & 0 & 0 & 0 & 1 & 0 & 4 & 0 & 0 & 5 \\
\hline Soft tissue & 3 & 2 & 0 & 3 & 0 & 0 & 0 & 0 & 0 & 0 & 8 \\
\hline Stomach & 3 & 5 & 8 & 9 & 6 & 13 & 15 & 9 & 11 & 6 & 85 \\
\hline Testes & 0 & 0 & 0 & 1 & 2 & 0 & 0 & 0 & 0 & 0 & 3 \\
\hline Thigh & 0 & 0 & 0 & 0 & 4 & 3 & 0 & 1 & 2 & 0 & 10 \\
\hline Thyroid & 0 & 0 & 0 & 3 & 1 & 2 & 1 & 3 & 1 & 0 & 11 \\
\hline Tongue & 1 & 1 & 0 & 0 & 1 & 1 & 0 & 1 & 0 & 0 & 5 \\
\hline Uterus & 2 & 3 & 3 & 3 & 1 & 6 & 3 & 3 & 0 & 3 & 27 \\
\hline Vagina & 0 & 2 & 1 & 0 & 1 & 0 & 2 & 2 & 0 & 0 & 8 \\
\hline Vocal cord & 0 & 0 & 0 & 0 & 0 & 1 & 0 & 0 & 0 & 0 & 1 \\
\hline Vulva & 0 & 0 & 0 & 0 & 1 & 0 & 0 & 0 & 0 & 0 & 1 \\
\hline Total & 226 & 219 & 186 & 204 & 303 & 256 & 236 & 216 & 265 & 135 & 2,246 \\
\hline
\end{tabular}


Table 2. Cancer incidence by categories of various cancer sites from UITH registry from 2007-2016

\begin{tabular}{cc}
\hline Cancer type & Incidence \\
\hline Oral cavity and Pharynx & 16 \\
Digestive system & 435 \\
Respiratory system & 64 \\
Bones and joints & 28 \\
Soft tissue & 10 \\
Skin & 23 \\
\hline Breast & 714 \\
\hline Female genital system & 250 \\
Male genital system & 300 \\
Urinary system & 74 \\
Eye & 61 \\
Brain & 3 \\
\hline Endocrine system & 10 \\
Lymphoma & 3 \\
Blood & 29 \\
Kaposi sarcoma & 1 \\
Others (Unspecified) & 219 \\
Total & 2,246 \\
\hline
\end{tabular}

Table 3. Some selected rare cancer groups in Ilorin,

Kwara state

\begin{tabular}{|cc|}
\hline Cancer type & Incidence \\
\hline Brain & 3 \\
Thyroid & 10 \\
\hline Cervix & 178 \\
\hline Vulva & 1 \\
\hline Vagina & 8 \\
\hline Testis & 3 \\
\hline Penis & 2 \\
Eye & 61 \\
\hline Non-Hodgkin & 3 \\
\hline Kaposi sarcoma & 1 \\
\hline
\end{tabular}

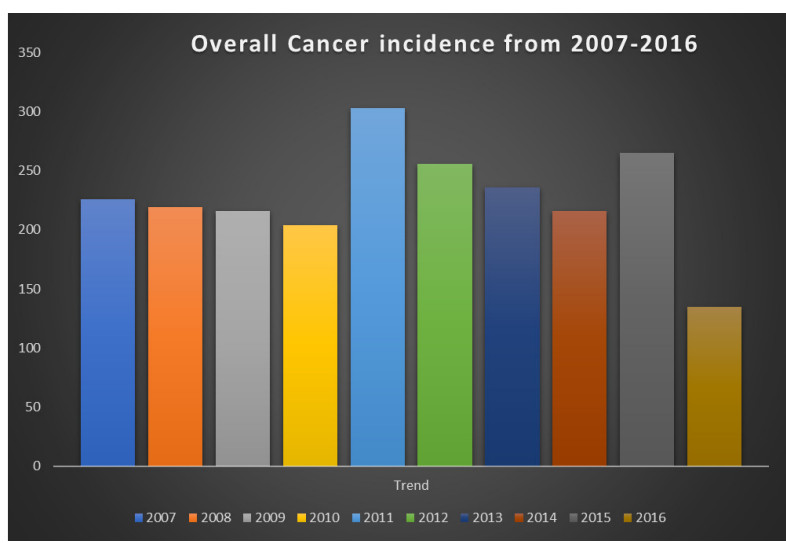

Fig. 1. Prevalence of cancer between 2007-2016

The choice of the used variables within the present investigation was based on specific risk factors that have been reported by previous studies (Goldberg et al., 1999; Okobia, 2003; Galea et al., 2004; Dreiher, 2005; Galobardes et al., 2006; Kanavos, 2006; de Kok et al., 2008; Ferlay et al., 2010; Frimpong-Boateng, 2010; Menvielle et al., 2010; Merletti et al., 2010; Ogundiran et al., 2010). The cancer data collected includes both male and female. There are presented the most common and rare cancers in the registry by gender and age.
Table 4. Gender characteristic of some selected cancer groups in Ilorin, Kwara State

\begin{tabular}{ccc}
\hline Cancer type & Male & Female \\
\hline Breast & 44 & 670 \\
Cervix & 16 & 178 \\
Prostate & 295 & 0 \\
Liver & 93 & 52 \\
\hline Non-Hodgkin's lymphoma & 4 & 1 \\
Nephroblastoma & 0 & 1 \\
Leukaemia & 6 & 23 \\
Brain & 1 & 2 \\
Colorectal & 62 & 42 \\
\hline Others (rare cancers) & 370 & 386 \\
Total & 891 & 1,355 \\
\hline
\end{tabular}

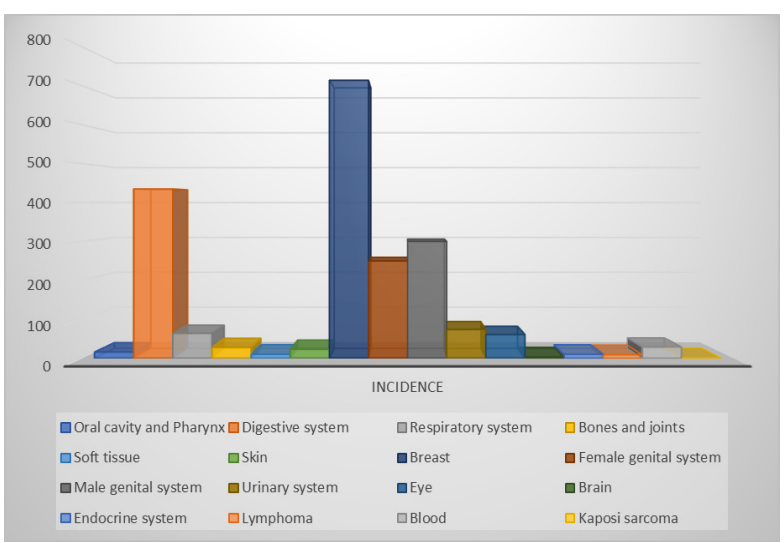

Fig. 2. Cancer incidence by various cancer sites from UITH registry from 2007-2016

The present study shows that of the years studied, cancer was more prevalent in 2011 and 2015, with cancers of the breast and prostate having the highest prevalence in males and females respectively (32.29\% and $13.34 \%)$ in Ilorin. A significant increase in the incidence of female cancer records compared to that of males was found. This might be due to the closeness of females with the health care system as a result of maternal, child care and other family related issues. Another reason might be due to the continuous awareness on breast and cervical cancer early detection. 


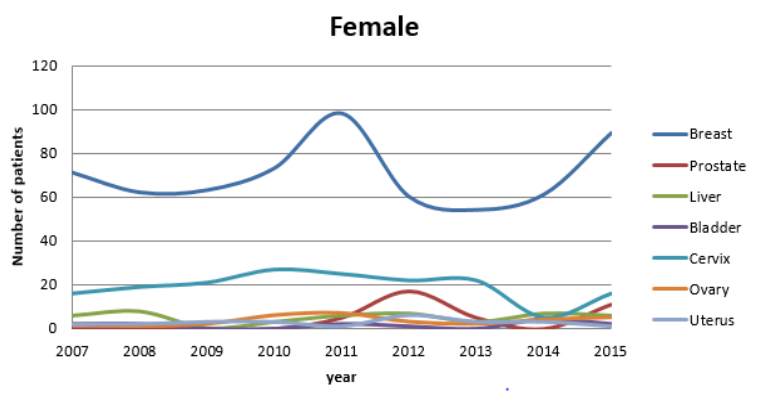

Fig. 3. Trends of common cancers in females (2007-2015)

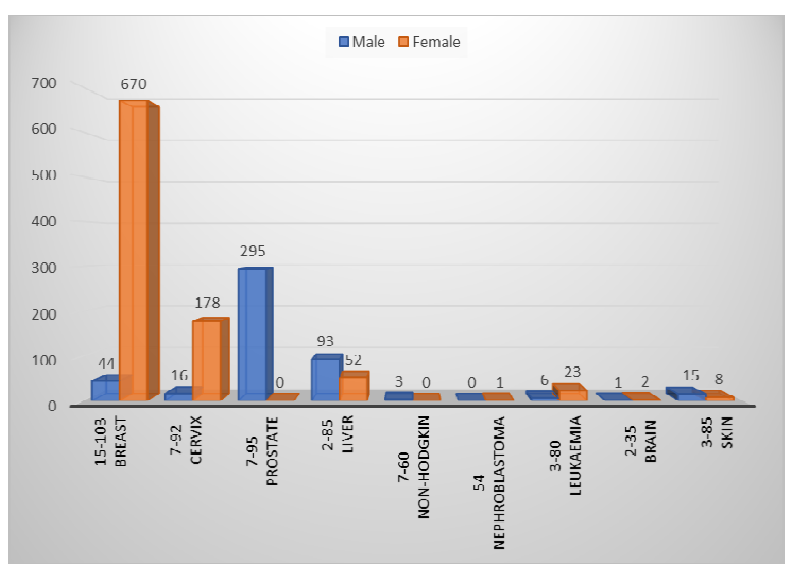

Fig. 5. Age characteristic of some selected cancer groups in Nigeria from the Ilorin registry

This assumption is similar to that of Jedy-Agba $e t$ al. (2013). Jemal et al. (2009) also reported higher cancer cases among women in West Africa and East Africa. However, this study contradicts the record of cancer occurrence at Ilorin and Zaria zones between 1987 and 1996, where more cases of the cancer groups, except that of the reproductive systems, were reported to be high in males.

The incidence rate of some common cancers among male and females in Nigeria according to WHO and Abdulkareem (2010) include breast, cervix, prostate, colorectal and liver cancer. The present data suggests the leading position of breast cancer and prostate cancer incidence in Ilorin, as observed in other registries within and outside the country (Adebamowo and Adekunle, 1999; Ogunbiyi and Shiitu, 1999; Okobia, 2003; Robert et al., 2010; Irabor, 2011). Moreover, the prevalence of these cancers is also common in early youth age.

It could probably be suggested that such occurrence is due to the fact that the factors that determine the incidence of most cancers are mostly exogenous or environmentally driven (Hiatt et al., 1977). They include exposures to western lifestyle or occupational hazards, pollutants in air, water and food supply, which predisposes the individual to cancer. Furthermore, some genetic factors (like hereditary) can also influence an individual's susceptibility to carcinogens. These views are similar to those of Faggiano et al. (1997) and Ferlay et al. (2010), who linked the cancer groups to divergent factors of westernisation of lifestyle and exposure to bacteria/viral infections.

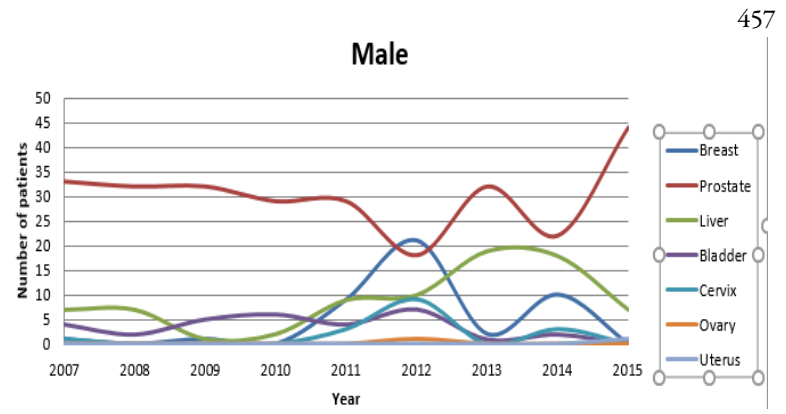

Fig. 4. Trends of common cancers in males (2007-2015)

In the current study, cervical cancer was reported $11^{\text {th }}$ $(<2 \%)$ most prevalent in Ilorin between the periods of 2007 and 2016. The data also shows the reoccurrence in three out the nine years of study. The result contradicts the studies of Sitas et al. (2000), Piras et al. (2011), as well as the estimate of Globocan (2008), who described cervical cancer as the most common cancer among women in most sub-Saharan Africa countries and second most common after breast cancer in Nigeria, respectively. This suggests that the very low incidence of cervical cancer $(<2 \%)$ could definitely be due to poor screening coverage in Ilorin or due to the low awareness compared to that of breast cancer.

Kaposi's sarcoma incidence in the present investigation was very low, with just an occurrence $(<1 \%)$ within female. This result contradicts the result of Bah et al. (2001) and Jedy-Agba et al. (2013) who reported the prevalence in males. More so, it can be suggested that this difference is probably due to the extremely low prevalence of human herpes virus (HHV) in Ilorin, which thus leads to the low incidence of Kaposi sarcoma (0.05\%) as compared to Abuja $(8.4 \%)$ or Ibadan (3.9\%) (Akinwande et al., 2009). This is because higher Kaposi sarcoma incidence has been reported in HHV positive populations in Uganda and Zimbabwe. Therefore, the use of highly active antiretroviral therapy could also reduce the incidence of Kaposi sarcoma cancer (Parkin et al., 1999).

According to Gundrum and Go (2012), certain types of cancers are more prevalent in older age groups. These types amongst the oldest-old (as it is commonly referred to) are breast, colorectal, prostate and lung/bronchus cancers.

Data from the present study shows breast, cervical and leukaemia as the most common among the aged females (with breast cancer being the most prevalent), whereas, prostate, liver and skin cancer were most prevalent amongst the males of that age group. In contrast, brain and nonHodgkin cancer is among other cancers identified as being prevalent in children and youth than aged. Aging can result in age-related declines of physiological processes and decreased risk of cancer at older ages, due to reduced cellular proliferation and metabolism, both of which affects cancer's ability to evade the body. However aging and senescent cells may as well play an additional role in tumour formation, thereby favouring tumour growth, recurrence and metastasis through changes in the tissue microenvironment (Laberge et al., 2015).

In addition to natural aging, ultraviolet radiation, stress and anti-cancer therapies can also cause genotoxicity and damage to the DNA, similar to that of the aging process, hence, increase cancer prevalence. 
458

In spite of the hospital-based data relied on in the current study, it is obvious that there is limited report on cancer incidence in Ilorin, Nigeria. From the hereby record survey, it is reasonable to conclude that the specific up rise of cancer incidence across age groups can vary by lifestyle, gender, geographic region, age group and cancer type. Predisposing factors like tumorigenesis and neurodegeneration share cellular and genetic pathways, though in opposing, but mutually exclusive, directions. Furthermore, the immune system of individual, biological stressors, as well as some specific gene interaction with accumulated environmental factors, could also influence the spread of cancer. Hanson et al. (2015) also suggested that the association of such cancers with young adults is that rare cancers often have a larger genetic component to their aetiology than more common cancers.

Due to the current make-up and the inherent socioeconomic disparities in the developing world where there are more people with low life expectancy, differences in environmental health and public health policy in separate geographical regions, all could influence the increase or reduction of cancer risk (Nolen et al., 2017).

Majority of the common cancers are preventable or curable if detected early (Greenlee et al., 2010). However, many rare cancers can be highly fatal, and yet patients have a limited evidence base to seek clinical attention. Therefore, future investigations should be targeted on risk factors related to some cancer groups, especially those considered rare so as to provide useful information to population about possible signs and symptoms for diagnosis, and government agencies should provide relevant equipment and staff training to ease the treatment process.

\section{Conclusions}

It should be noted that control of diet, tobacco use, obesity and inactivity will not only control cancer, but other major non-communicable diseases such as diabetes, hypertension, strokes and heart attacks. In order to address the various challenges that contribute to cancer morbidity and mortality in Ilorin, it should be regarded as everybody's problem as it represents a tremendous burden on patients, families and society.

\section{Acknowledgements}

The authors thank the management and staff of the Cancer Section of University of Ilorin Teaching Hospital (UITH), Ilorin, Kwara State, Nigeria for their kind gesture during data collection for this study.

\section{References}

Adebamowo CA, Adekunle OO (1999). Case control study of epidemiological risk factors for breast cancer in Nigeria. British Journal of Surgery 86(5):665-668.

Akinwande O, Ogundiran T, Akarolo SA, Mamadu I, Dakum P, Blattner W, Adebamowo C (2009). Challenges in treating malignancies in HIV in Nigeria. Current Opinion in Oncology 21(5):455-461.
Ananya MD (2012). Cancer classification. News-Medical. Retrieved 2017 September 20 from http://www. Newsmedicalnet/health/CancerClassification.aspx, pp 1-3.

Bah E, Parkin DM, Hall AJ, Jack AD, Whittle H (2001). Cancer in the Gambia: 1988-97. British Journal ofCancer 84(9):1207-1214.

Bah E, Sam O, Whittle H, Ramanakumar A, Sankaranarayanan R (2011). Cancer survival in the Gambia, 1993-1997. IARC Scientific Publication 162:97-100.

de Kok IM, van Lenthe FJ, Avendano M, Louwman M, Coebergh JW, Mackenbach JP (2008). Childhood social class and cancer incidence: results of the globe study.Social Science \& Medicine 66(5):1131-1139.

Dreiher J, Novack V, Barachana M, Yerushalmi R, Lugassy G, Shpilberg O (2005). Non-Hodgkin's lymphoma and residential proximity to toxic industrial waste in southern Israel. Haematologica 90(12):1709-1710.

Durosinmi MA (2008). Cancer control in an economically disadvantaged setting. Nigeria. INCTR Newsletter. Retrieved 2008 May 19 from www.inctr.org/publications/2004_v05-n01_s02.shtml.

Faggiano F, Partanen T, Kogevinas M, Boffetta P (1997). Socioeconomic differences in cancer incidence and mortality. IARC Scientific Publications (138):65-176.

Ferlay J, Shin HR, Bray F, Forman D, Mathers C, Parkin DM (2008). Cancer incidence and mortality worldwide. GLOBOCAN 2008 IARC CancerBase No. 10 [Internet].Lyon, France: International Agency for Research on Cancer, 2 .

Ferlay J, Shin HR, Bray F, Forman D, Mathers C, Parkin DM (2010). Estimates of worldwide burden of cancer in 2008: GLOBOCAN 2008. International Journal ofCancer 127(12):2893-2917.

Frimpong-Boateng K (2010). Infectious disease and cancer in Africa - A medical and demographical reality. A keynote lecture presented at the "Global Health and Molecular Medicine: Our Common Future", Hannover. Retrieved 2017 October 23 from http: //www. ourcommonfuture.de.

Fritz A, Percy CL, JackA, Shanmugaratnam K, Sobin L, Parkin DM(2000). International classification of diseases for oncology. $3 \mathrm{rd}$ ed. (ICD-O-3). Geneva: World Health Organization.

Galea S, Nandi A, Vlahov D (2004). The social epidemiology of substance use. Epidemiologic Reviews 26(1):36-52.

Galobardes B, Shaw M, Lawlor DA, Lynch JW, Smith GD (2006). Indicators of socioeconomic position (part 1). Journal of Epidemiology \&Community Health 60(1):7-12.

Goldberg MS, Siemiatyck J, Dewar R, Désy M, Riberdy H (1999). Risks of developing cancer relative to living near a municipal solid waste landfill site in Montreal, Quebec, Canada. Archives of Environmental Health: An International Journal 54(4):291-296.

Greenlee RT, Goodman MT, Lynch CF, Platz CE, Havener LA, Howe HL (2010). The occurrence of rare cancers U. S. adults, 1995-2004. Public Health Reports 125(1):28-43

Gundrum JD, Go RS (2012). Cancer in the oldest old in the United States: current statistics and projections. Journal of Geriatric Oncology 3(4):299-306.

Hanson HA, Smith KR, Stroup AM, Harrell CJ (2015). An age-periodcohort analysis of cancer incidence among the oldest old, Utah 19732002. Population Studies 69(1):7-22. 
Hiatt HH, Watson JD, Winsten JA (1977). Origins of human cancer. Book A. Incidence of cancer in humans; Book B. Mechanisms of carcinogenesis; Book C. Human risk assessment. Cold Spring Harbor Laboratory, Box 100, Cold SpringHarbor, NY 11724, USA.

Ikawo OE (2013). A literature review on cancer in Nigeria. Department of biochemistry, College of medicine, University of Lagos. Retrieved 2017 October 25 from http://www.academia.edu/3310884/Cancer _In_Nigeria.

Irabor DO (2011). Colorectal carcinoma: Why is there a lower incidence in Nigerians when compared to Caucasians? Journal of Cancer Epidemiology doi:10.1155/2011/675154.

Jedy-AgbaE,Curado MP, Ogunbiyi O, Oga E, Fabowale T, et al., Osinubi P (2013). Cancer incidence in Nigeria: a report from population-based cancer registries. Cancer Epidemiology 36(5):e271-278.

Jemal A, Siegel R, Ward E, Hao Y, Xu J, Thun MJ (2009). Cancer statistics. CA: a Cancer Journal for Clinicians 59(4):225-249.

Kanavos P (2006). The rising burden of cancer in the developing world. Annals ofOncology 17(8):viii 15-viii 23.

Laberge RM, Sun Y, Orjalo AV, Patil CK, Freund A, et al., Limbad C (2015). MTOR regulates the pro-tumorigenic senescence-associated secretory phenotype by promoting IL1A translation. Nature Cell Biology 17(8):1049-1061.

Lambo EO (2007). Press release on state of health in Nigeria. Retrieved 2017 Aug28.

Malcolm RA (2001). Cancer. In: Encyclopedia of Life Sciences. Nature Publishing Group, Imperial College School of Medicine. London, UK pp 420-428.

Menvielle G, Boshuizen H, Kunst AE, Vineis P, Dalton SO et al, RaaschouNielsen O (2010). Occupational exposures contribute to educational inequalities in lung cancer incidence among men: Evidence from the EPIC prospective cohort study. International Journal of Cancer 126(8):1928-1935.

Merletti F, Galassi C, Spadea T (2011). The socioeconomic determinants of cancer.Environmental Health 10(1):S7.

Nolen SC, Evans MA, Fischer A, Corrada MM, Kawas CH, Bota DA (2017). Cancer- incidence, prevalence and mortality in the oldest old. A comprehensive review. Mechanism of Ageing and Development 164:113-126.
Ogunbiyi JO, Shittu OB (1999). Increased incidence of prostate cancer in Nigerians. Journal of the National Medical Association 91(3):159.

Ogundiran TO, Huo D, Adenipekun A, Campbell O, Oyesegun R, et al, Olopade OI (2010). Case-control study of body size and breast cancer risk in Nigerian women. American Journal of Epidemiology 172(6):682-690.

Okobia MN (2003). Cancer care in Sub-Saharan Africa-urgent need for population-based cancer registries. Ethiopian Journal of Health Development 17(2):89-98.

Okobia MN, Aligbe JU (2005). Pattern of malignant diseases at the University of Benin Teaching Hospital. Tropical Doctor 35(2):91-92.

Olusegun O (2014). Spatial and socio-demographic disparities of cancer morbidity in Nigeria: Patterns and factors. Malaysian Journal of Society and Space 10(1):25-35.

Parkin DM, Wabinga H, Nambooze S, Wabwire-Mangen F (1999). AIDS-related cancers in Africa: maturation of the epidemic in Uganda. Aids 13(18):2563-70.

Piras F, Piga M, De Montis A, Zannou AR, Minerba L, et al., Sirigu P (2011). Prevalence of human papillomavirus infection in women in Benin, West Africa. VirologyJournal 8(1):514.

Ries LG, Melbert D, Krapcho M, Mariotto A, Miller BA, Feuer EJ (2008). SEER cancer statistics review, 1975-2004. National Cancer Institute. Retrieved 2017 September 25 from http: //seer.cancer.gov/csr/1975_2004.

Sitas F, Pacella-Norman R, Carrara H, Patel M, Ruff P, et al., Connor M (2000). The spectrum of HIV-1 related cancers in South Africa. International Journal of Cancer 88(3):489-492.

Sylla BS, Wild CP (2012). A million Africans a year dying from cancer by 2030: what can cancer research and control offer to the continent? International Journal of Cancer 130(2):245-250.

Torre LA, Bray F,Siegel RL, Ferlay J, Lortet-Tieulent J, Jemal A (2015). Global cancer statistics, 2012. CA Cancer Journal of Clinicians 65(2):87-108.

WHEDA-Nigeria (2004). The women's health and economic development association Newsletter. Retrieved 2017 November 25 from https://www.healthresearchweb.org/en/nigeria/cso_4367

WHO (2005). Global Action on Cancer-Update Version, Global Cancer Controlpp 1-22. 